\title{
Outcomes of Hypospadias Surgery Performed by Different Surgeons Under the Supervision of an Experienced Pediatric Urology Surgeon
} Pediyatrik Ürolojide Uzmanlaşmış Bir Cerrah Eşliğinde Yapılan Hipospadias Tamiri Sonuçları

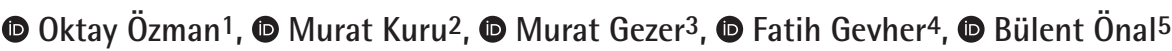 \\ 1 University of Health Sciences, Gaziosmanpaşa Taksim Training and Research Hospital, Clinic of Urology, İstanbul, Turkiye \\ 2 Yeditepe University Faculty Medical, Department of Urology, İstanbul, Turkiye \\ ${ }^{3}$ Adıyaman University Faculty Medical, Training and Research Hospital, Clinic of Urology, Adıyaman, Turkiye \\ ${ }^{4}$ Bezmialem Vakıf University Faculty Medical, Department of Urology, İstanbul, Turkiye \\ 5 Istanbul University Cerrahpaşa Faculty Medical, Department of Urology, İstanbul, Turkiye
}

\section{What's known on the subject? and What does the study add?}

Hypospadias repair results depend on the surgeons experience. The rates of success and complications of the hypospadias surgeries done by different surgeons with an accompanying pediatric urologist are similar with the series done by experienced pediatric urology surgeons.

\begin{abstract}
Objective: Hypospadias is one of the most common congenital anomalies among males. Hypospadias repair is still a challenging issue due to its results and frequently seen complications. The most commonly used techniques are the meatal advancement with glansplasty incorporated and tubularized incised plate urethroplasty. The experience of the surgeon is an important factor that influence the success of the surgery. In the literature, there are not enough data about the success of these operations done by different surgeons under the supervision of a pediatric urologist. Materials and Methods: Records of 98 patients who underwent hypospadias surgery performed under the supervision of a pediatric urologist between 2008 and 2015 were retrospectively investigated. Patients who developed fistula after operation and those who did not were divided into two groups. The two groups were compared according to hyposdias type, history, operation type and age.

Results: A total of 98 patient were included in the study. The mean age was $8.58 \pm 8.3$ years. Eighty six ( $88 \%)$ patients had distal and 12 (12\%) had proximal hypospadiasis. Twenty two (22\%) patients developed fistula. There was no statistically significant difference in history and type of hypospadias and age group (child vs adult) between the two groups. The mean age of the non-fistula group was statistically significantly lower than the fistula group $(p=0.0169)$.

Conclusion: The rates of success and complications of the hypospadias surgeries performed by different surgeons under the supervision of an experienced pediatric urologist are similar with the series done by experienced pediatric urologists.
\end{abstract}

Keywords: Hypospadias, Fistula, Hypospadias repair

Öz

Amaç: Hipospadias erkeklerde en sık görülen doğumsal anomalilerden biridir. Hipaspadias tamiri ise sonuçları ve sık görülen komplikasyonlar nedeniyle hala zorlu bir konudur. En sık tercih edilen yöntemler Meatal İlerletme ve Glanüloplasti ile Tübülarize İnsize Plak Üretroplastisi'dir. Cerrahın deneyimi tekniğin başarısını belirleyen önemli bir faktördür. Çocuk üroloji alanında uzmanlaşmış bir cerrah eşliğinde gerçekleştirilen operasyonların sonuçları hakkında literatürde yeterli veri yoktur.

Gereç ve Yöntem: 2008-2015 yılları arasında çocuk ürolog eşliğinde hipospadias tamiri yapılan 98 çocuğun kayıtları retrospektif olarak incelendi. Hastalar operasyon sonrası fistül gelişme durumlarına göre iki gruba ayırıldı. Hipospadias tipi, hipospadias öyküsü, operasyon tipi ve yaş grubu açısından iki grup karşılaştırıldı.

Correspondence: Oktay Özman MD, University of Health Sciences, Gaziosmanpaşa Taksim Training and Research Hospital, Clinic of Urology, İstanbul, Turkiye Phone: +90 2124143700 E-mail: ozmanoktay@hotmail.com ORCID-ID: orcid.org/0000-0003-2499-8947

Received: 13.04 .2018

Accepted: 03.12.2018

Cite this article as: Özman O, Kuru M, Gezer M, Gevher F, Önal B. Outcomes of Hypospadias Surgery Performed by Different Surgeons under the Supervision of an Experienced Pediatric Urology Surgeon. J Urol Surg 2019;6(2):144-147.

oCopyright 2019 by the Association of Urological Surgery / Journal of Urological Surgery published by Galenos Publishing House. 


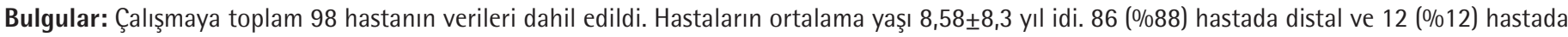
proksimal hipospadias mevcuttu. Toplam 22 (\%22) hastada fistül gelişimi izlendi. Başarılı olguların yaş ortalaması fistül gelişen hastalardan istatistiksel olarak anlamlı oranda düşüktü $(p=0,0169)$. İki grup arasında hipospadias tipi, hipospadias öyküsü ve yaş grubu açısından istatistiksel anlamlı fark saptanmadı.

Sonuç: Çocuk üroloji alanında uzmanlaşmış bir cerrah eşliğinde, değişik cerrahlar tarafından yapılan hipospadias onarımlarında görülen başarı ve komplikasyon oranları deneyimli pediatrik üroloji uzmanları tarafından yapılan serilere benzer özelliktedir.

Anahtar Kelimeler: Hipospadias, Fistül, Hipospadias tamiri

\section{Introduction}

Hypospadias is one of the most common congenital anomalies among males. It occurs in approximately 1 in 150-300 newborns (1). It is more prevalent in whites than in African Americans. Hypospadias can be defined as an arrest in normal development of the urethra which leads to a wide range of abnormalities, with the urethral opening being anywhere along the shaft of the penis, within the scrotum, or even in the perineum. Due to related embryological processes, usually ventral prepitual defect, chordee or situations such as glandular tilt may be involved. Penile development is completed under the effects of androgens. Conditions, such as undescended testis and inguinal hernia, can accompany hypospadias. Hypospadias can also be found as one of the multiple phenotypic characteristics of sexual disturbances.

Hypospadias repair is challenging due to its results and frequently seen complications. From Anthyllus, known as the first hypospadias surgeon, to Galen, who underlined the importance of the chordee and to todays Snodgrass, many surgeons have defined hundreds of surgical techniques (2). The most commonly used techniques are meatal advancement and glanuloplasty incorporated (MAGPI) and tubularized incisedplate urethroplasty (TIPU) (3). There are many factors, such as the type of the hypospadias, surgery time, suture material, techniques, that affect the results of the surgery. As in every surgery, the experience of the surgeon is also an important factor for surgical outcomes. Many authors suggest that hypospadias surgery should be performed by only surgeons specialised in the field of pediatric surgery. Surgery success, which is evaluated according to the complication rates, can be gained only by sufficient experience and choosing the right method (4).

Every year, many urology residents perform a large number of hypospadias surgeries during the first years of their residency. In the literature, there are not enough data about the success rate of these operations done under the supervision of a pediatric urologist. In this study, we investigated the success rate of hypospadias surgery performed by different surgeons under the supervision of a pediatric urologist.

\section{Materials and Methods}

Records of 98 patients who underwent hypospadias surgery performed under the supervision of a pediatric urologist between 2008 and 2015 were retrospectively investigated. The pediatric urologist observed the operations from outside the sterile field. He mentored the surgeons when necessary and rarely intervened directly. Age, type of hypospadias and surgery, previous surgeries, follow-up period and complications were recorded. Patients younger than 17 years were recorded as children and those older than 17 years were recorded as adults. Based on the location, glanular, coronal, subcoronal and midshaft hypospadias were classified as distal, and penoscrotal and perineal ones were classified as proximal hypospadias.

Adult patients and parents of pediatric patients provided written informed consent for the participation in this retrospective study. Ethics committee approval was not applied because of the retrospective design of the study. The data was analyzed with the Statistical Package for the Social Sciences v. 16 (SPSS Inc, Illinois, USA). Student's t-test and Fisher's exact test were used in statistical analysis. A p value of less than 0.05 was considered statistically significant.

\section{Results}

A total of 98 patients were included in the study. The mean age of the patients was $8.58 \pm 8.3$. Eighty-six ( $88 \%)$ patients had distal and $12(12 \%)$ had proximal hypospadiasis (Table 1). Sixteen (16\%) patients had a history of one or more hypospadias repair surgery, $82(84 \%)$ had primary hypospadias surgery. For distal hypospadias, 68 (79\%) patient had TIPU, 18 (21\%) had MAGPI; all the proximal hypospadias were repaired using TIPU. A total of $22(22 \%)$ patients who underwent distal hypospadias repair developed fistula (Table 2); 17 (21\%) had primary hypospadias repair $5(31 \%)$ had a previous (secondary-tertiary) hypospadias surgery. The rate of fistula development after TIPU and MAGPI was $23 \%(19 / 80)$ and $17 \%(3 / 18)$, repectively. $34 \%$ of adults and $21 \%$ of children developed fistula (Table 1). Exept that in one patient who was treated with catheter dilatation and steroid, all the fistulas were repaired by one-step surgical procedure. None of the patients had meatal stenosis, urethral diverticulum or glandular separation. 
During statisticall analysis, patients who developed fistula and those who did not were divided into two groups. Age of the non-fistula group was statistically significantly lower than the fistula group ( $p=0.0169$ ). There was no statistically significant difference in hyposdias type, history and age group (children versus adults) between the two groups.

\section{Discussion}

Hypospadias repair is still one of the challenging fields of urogenital reconstructive surgery. Besides the type of surgery, age and the level of the hypospadias, experience of the surgeon is an important factor affecting surgical outcomes. There are many studies that investigated learning curve. In most of the studies, it has been shown that complication rates decreased significantly after 2 years of experience. In a study conducted by Hafez and Helmy (5) in 2012, the same surgeon performed hypospadias repairs in 2 years after receiving specialization in pediatric urology and the cases he did in the following period were compared. The difference between the success rate in the first two years $(65 \%)$ and in following period (91\%) was statistically significant (5).

In our country, the training period for urology residency is 5 years. During this time, hypospadias surgeries are done under the supervision of a pediatric urologist. There are few studies in the literature on the results of operations performed by urology residents.

Table 1. Results

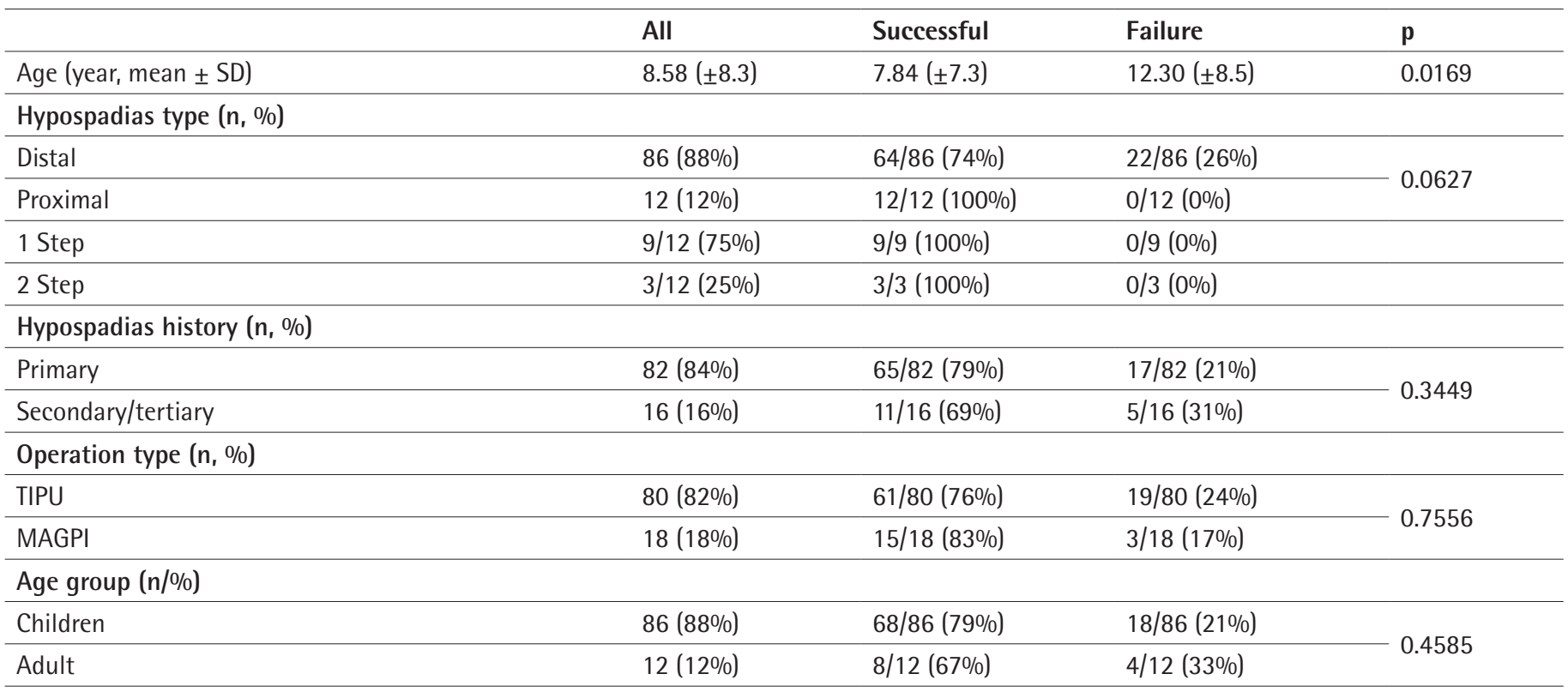

SD: Standard deviation, TIPU: Tubularized incised plate urethroplasty, MAGPI: Meatal advancement and glanuloplasty

Table 2. Complications

\begin{tabular}{|c|c|c|c|}
\hline & Fistula & Glandular separation & Stenosis \\
\hline \multicolumn{4}{|c|}{ Hypospadias type (n, \%) } \\
\hline Proximal & $0 / 12(0 \%)$ & $0 / 12(0 \%)$ & $0 / 12(0 \%)$ \\
\hline Distal & $22 / 86(25 \%)$ & 0/86 (0\%) & $0 / 86(0 \%)$ \\
\hline \multicolumn{4}{|c|}{ Hypospadias history $(n, \%)$} \\
\hline Primary & $16 / 90(18 \%)$ & 0/90 (0\%) & $0 / 90(0 \%)$ \\
\hline Secondary/tertiary & $6 / 8(75 \%)$ & $0 / 8(0 \%)$ & $0 / 8(0 \%)$ \\
\hline \multicolumn{4}{|c|}{ Operation type $(n, \%)$} \\
\hline TIPU & $19 / 80(23 \%)$ & $0 / 80(0 \%)$ & $0 / 80(0 \%)$ \\
\hline MAGPI & $3 / 18(17 \%)$ & 0/18 (0\%) & $0 / 18(0 \%)$ \\
\hline \multicolumn{4}{|l|}{ Age group (n/\%) } \\
\hline Children & $18 / 86(21 \%)$ & $0 / 86(0 \%)$ & $0 / 86(0 \%)$ \\
\hline Adult & $4 / 12(34 \%)$ & $0 / 12(0 \%)$ & $0 / 12(0 \%)$ \\
\hline
\end{tabular}

TIPU: Tubularized incised plate urethroplasty, MAGPI: Meatal advancement and glanuloplasty 
In 2010, Wilkinson et al. (6) showed in their metaanalysis involving 23 studies that in patients, who underwent distal hypospadias repair, the incidence of urethral fistulae with TIP repair and Mathieu technique was 3.8\% and 5.3\% respectively. In a meta-analysis involving 10 studies, Wang et al. (7) showed that the fistula rate after TIPU was 7.99\%. In our study, the fistula rate after TIPU was $24 \%$.

It is also necessary to evaluate the high fistula rates considering the age of the patients. A study done by Hensle et al. (8) in 2001 showed a significant relationship between age and complications. Also a smilar result was found in our study $(p=0.0169)$. Today it is accepted that hypospadias surgery should be done before the age of 1 year. The mean age of the patients in our study was 8.58 years. The fistula development rate in patients younger than 1 year was found to be smilar with the literature (7\%).

In a 2002 review, Snodgrass reported that no fistulas had developed in his series of proximal hypospadias repairs (9). In our study, there were no fistula development after proximal hypospadias repair.

Considering that many of the surgeons performing hypospadias repair in the aforementioned studies had years of experience, it will also be necessary to look at the subject from a different perspective. Horowitz and Salzhauer (4) who reported 5 years of experience of a full-time practising paediatric urologist immediately after completing a 2-year fellowship in paediatric urology. showed that the fistula rates decreased by $12.7 \%$ in the last two years compared to the first two years (4). According to the study, while the fistula rates were $20.6 \%$ during the first two years, it decreased to $7.9 \%$ in the last two years. The highest fistula rate was detected in the first year (23\%).

In our study, the experience of the surgeons, who performed hypospadias surgeries under the supervision of a pediatric urologist was less than one year and the fistula rate was $22 \%$.

\section{Study Limitations}

Our study has several limitations. The data were collected longitudinally and verified retrospectively, which could have introduced error. The lack of the number of proximal hypospadias cases in our study is a factor that complicates statistical significance. Besides, our study was not a comperative study. Despite these limitations, the outcomes of the hypospadias surgeries performed by different surgeons under the supervision of an experienced pediatric urologist are similar with the series done by experienced pediatric urologists. Further prospective studies are warranted.

\section{Conclusion}

The rates of success and complications of hypospadias surgeries performed by different surgeons under the supervision of an experienced pediatric urologist are similar with the series done by experienced pediatric urologists.

\section{Ethics}

Ethics Committee Approval: Retrospective study.

Informed Consent: It was taken.

Peer-review: Externally peer-reviewed.

\section{Authorship Contributions}

Concept: B.Ö., Design: B.Ö., 0.0̈., Data Collection and/or Processing: M.K., 0.0̈., Analysis and/or Interpretation: 0.0̈. Literature Research: 0.Ö., Writing: 0.Ö., B.Ö.

Conflict of Interest: No conflict of interest was declared by the authors.

Financial Disclosure: The authors declared that this study received no financial support.

\section{References}

1. Baskin LS, Himes $\mathrm{K}$, Colborn T. Hypospadias and endocrine disruption: is there a connection? Environ Health Perspect 2001;109:1175-1183.

2. Hadidi AT. History of hypospadias: Lost in translation. J Pediatr Surg 2017;52:211-217.

3. Snodgrass W, Bush N. Primary hypospadias repair techniques: A review of the evidence. Urology Annals. 2016;8(4):403-8.

4. Horowitz M, Salzhauer E. The 'learning curve' in hypospadias surgery. BJU international 2006;97:593-596.

5. Hafez AT, Helmy T. Tubularized Incised Plate Repair for Penoscrotal Hypospadias: Role of Surgeon's Experience. Urology 2012;79:425-427.

6. Wilkinson DJ, Farrelly P, Kenny SE. Outcomes in distal hypospadias: A systematic review of the Mathieu and tubularized incised plate repairs. J Pediatr Urol 2012;8:307-312.

7. Wang $F, X u Y$, Zhong $H$. Systematic review and meta-analysis of studies comparing the perimeatal-based flap and tubularized incised-plate techniques for primary hypospadias repair. Pediatr Surg Int 2013;29:811821.

8. Hensle TW, Tennenbaum SY, Reiley EA, Pollard J. HYPOSPADIAS REPAIR IN ADULTS: ADVENTURES AND MISADVENTURES. J Urol 2001;165:77-79.

9. Snodgrass WT. Tubularized incised plate hypospadias repair: indications, technique, and complications. Urology 1999;54:6-11. 